\title{
FORMULASI JELLY DRINK BERBASIS RUMPUT LAUT MERAH DAN Spirulina platensis
}

\section{Formulation of Red Seaweed and Spirulina platensis Based Jelly Drinks}

\author{
Wini Trilaksani*, Iriani Setyaningsih, Dita Masluha \\ Departemen Teknologi Hasil Perairan, Fakultas Perikanan dan Ilmu Kelautan, \\ Institut Pertanian Bogor, Kampus IPB Dramaga, Jalan Agatis, Bogor 16680 Jawa Barat. \\ Telepon (0251) 8622909-8622907, Faks. (0251) 8622907 \\ *Korespondensi: wini_trilaks@yahoo.co.id \\ Diterima 09 Januari 2015/Disetujui 25 April 2015
}

\begin{abstract}
Abstrak
Jelly drink yang ada di pasaran umumnya menggunakan pemanis, perisa, dan pewarna sintetik serta memiliki kandungan gizi yang rendah, sehingga perlu dikembangkan jelly drink yang lebih sehat, misalnya dengan memanfaatkan rumput laut dan Spirulina. Penelitian ini bertujuan untuk mendapatkan formula terbaik jelly drink dengan berbahan dasar rumput laut (Eucheuma cottonii) dan Spirulina platensis serta membandingkan karakteristik (gizi dan antioksidan) jelly drink yang ditambah Spirulina hasil kultur dengan jelly drink yang ditambah Spirulina komersial. Jelly drink dengan penambahan Spirulina komersial $(0,2 \%$; $0,4 \%$; dan $0,6 \%)$ memiliki kadar protein $(1,218-2,750) \%$ dan nilai $\mathrm{IC}_{50}(3363,5-6070)$ ppm. Berdasarkan uji bayes, Jelly drink Spirulina komersial 0,4\% merupakan produk terpilih. Jenis Spirulina (komersial dan kultur) yang ditambahkan tidak memberikan pengaruh berbeda $(p<0,05)$ terhadap hasil uji hedonik dan aktivitas antioksidan namun memberikan pengaruh nyata terhadap kadar protein. Jelly drink yang ditambah Spirulina kultur 0,4\% menghasilkan energi yang lebih besar yakni 92 kkal dibandingkan dengan Jelly drink Spirulina yang ditambah komersial 0,4\% yakni 79 kkal.
\end{abstract}

Kata kunci: Jelly drink, protein, rumput laut, serat pangan, Spirulina platensis

\begin{abstract}
Generally, jelly drinks in the market contain synthetic sweeteners, coloring and flavoring agents, as well as low in nutrients content, therefore it needs to be developed in order to obtain more healthy product by adding seaweed and Spirulina. The aims of this research were to determine the best formula of jelly drinks with seaweed (Eucheuma cottonii) and Spirulina platensis and to compare the characteristics (nutrients and antioxidant activity) of jelly drinks made from culture-based Spirulina and from commercial Spirulina. Jelly drinks made from commercial Spirulina (0.2\%; 0.4\%; and 0.6\%) had protein content $1.218-2.750 \%$ $(\mathrm{db})$ and the $\mathrm{IC}_{50}$ value was 3363.5-6070 ppm. Bayes test showed that jelly drink with commercial Spirulina $0.4 \%$ was the selected product and was used as the reference formula on this research. Types of Spirulina (commercial and culture) gave no significant effect $(p>0.05)$ to the hedonic test results and antioxidant activity however affected significantly on protein content $(p<0.05)$. Jelly drink supplemented with $0.4 \%$ of culture-based Spirulina produced $92 \mathrm{kcal}$ of energy; meanwhile the jelly drink with $0.4 \%$ of commercial Spirulina produced $79 \mathrm{kcal}$ of energy.
\end{abstract}

Keywords: Dietary fiber, jelly drink, protein, seaweed, Spirulina platensis

\section{PENDAHULUAN}

Upaya peningkatan kesejahteraan penduduk di negara berkembang telah mendorong terjadinya perubahan gaya hidup yang ditandai dengan kurangnya aktivitas fisik serta asupan cenderung tinggi energi dan rendah serat. Serat merupakan komponen penting dalam bahan pangan, terutama dalam menjaga kesehatan dan keseimbangan fungsi sistem pencernaan, mencegah penyakit kanker usus dan membantu menurunkan berat badan. Hasil 
penelitian Hardoko (2008) menunjukkan bahwa serat rumput laut (Eucheuma cottonii) dalam bentuk gel pada konsentrasi 15\% dari jumlah ransum mampu menormalkan darah hiperkolesterolemia tikus wistar. Rumput laut (Eucheuma cottonii) dengan kandungan serat pangan, mineral dan komponen lainnya dapat dikembangkan menjadi produk yang digemari masyarakat contohnya jelly drink.

Jelly drink yang ada di pasaran umumnya menggunakan karagenan (sebagai pembentuk gel), pemanis, pewarna, pengawet dan perasa sintetik serta kandungan gizi yang rendah sehingga perlu pengembangan produk sebagai contoh pemanfaatan rumput laut dan Spirulina untuk meningkatkan nilai gizinya. Rumput laut tidak hanya berfungsi sebagai pembentuk gel tetapi juga menambah kandungan gizi produk yaitu mineral, vitamin dan komponen bioaktif, sedangkan Spirulina dapat dimanfaatkan sebagai pewarna alami jelly drink.

Spirulina merupakan mikro alga dengan dinding sel lembut yang terbentuk dari gula dan protein. Estrada et al. (2001) menunjukkan bahwa Spirulina mengandung $62 \%$ protein, antioksidan, dan mengandung fikosianin yang dapat dimanfaatkan sebagai pewarna alami. Penelitian ini bertujuan untuk mendapatkan formula jelly drink berbasis rumput laut (Eucheuma cottonii) dan Spirulina platensis yang dapat diterima oleh panelis dan membandingan karaktesistik jelly drink yang ditambah Spirulina hasil kultur dengan formula terbaik jelly drink Spirulina komersial.

\section{BAHAN DAN METODE Bahan dan Alat}

Bahan utama yang dipergunakan adalah Spirulina platensis, rumput laut (Eucheuma cottonii). bibit Spirulina platensis, media Walne, media Zarrouk teknis, air laut 15 ppt, bahan untuk analisis proksimat, analisis serat pangan dan bahan uji antioksidan. Alat yang digunakan diantaranya oven (Yamato Drying Oven DV 41), tanur (Yamato Muffle Furnance FM38), dan spektrofotometer UV-VIS Hitachi U-2800.

\section{Metode Penelitian}

Penelitian ini terdiri atas penelitian pendahuluan dan penelitian utama. Perlakuan yang diberikan pada penelitian pendahuluan adalah perbedaan konsentrasi rumput laut (5\%; 7\%; dan 9\%). Penelitian utama dilakukan dalam tiga tahap. Tahap 1 yakni proses formulasi jelly drink dengan perlakuan konsentrasi Sprulina komersial yakni $0,2 \% ; 0,4 \%$; dan $0,6 \%$. Formula terbaik dipilih berdasarkan hasil uji kepentingan menggunakan metode Bayes (Marimin 2004) dengan kriteria yakni hasil uji hedonik, kadar protein dan aktivitas antioksidan. Tahap 2 kultivasi Spirulina platensis dan karakterisasi kimia biomassa Spirulina platensis. Tahap 3 pembuatan jelly drink dengan penambahan Spirulina hasil kultur.

Analisis yang dilakukan pada jelly drink dengan penambahan Spirulina kultur yakni uji hedonik (BSN 2011), uji proksimat (BSN 2006), uji serat pangan (Sulaeman et al. 1993), uji aktivitas antioksidan (Molyneux 2004) dan juga perhitungan angka kecukupan gizi (AKG). Rancangan percobaan yang digunakan dalam penelitian ini adalah rancangan acak lengkap (RAL) yang diacu dari Mattjik dan Jaya (2006), sedangkan uji hedonik diolah menggunakan metode Kruskal Wallis.

\section{HASIL DAN PEMBAHASAN \\ Penelitian Pendahuluan}

Penilaian rata-rata panelis terhadap daya sedot jelly drink berkisar antara 6,13 sampai 7,13 (agak suka hingga suka) (Gambar 1). Perbedaan konsentrasi rumput laut memberikan pengaruh $(p<0,05)$ terhadap nilai kesukaan panelis terhadap daya sedot jelly drink. Hasil uji lanjut Duncan menunjukkan bahwa perlakuan konsentrasi rumput laut 7\% 
berbeda nyata dengan konsentrasi rumput laut $5 \%$ dan $9 \%$. Daya sedot yang paling disukai adalah penambahan rumput laut dengan konsentrasi 7\%. Penambahan rumput laut konsentrasi 5\% mengakibatkan tidak terlalu banyak gel yang terbentuk sedangkan pada penambahan rumput laut konsentrasi $9 \%$ terlalu banyak gel (lebih sulit disedot) yang terbentuk sehingga tidak disukai oleh panelis.

\section{Penelitian Utama Tahap 1 Hasil Uji Hedonik}

Uji hedonik yang dilakukan meliputi penampakan, warna, aroma, rasa dan daya sedot. Peningkatan konsentrasi Spirulina mengakibatkan peningkatan kesukaan panelis (Gambar 1) terhadap penampakan dan aroma jelly drink Spirulina. Perbedaan konsentrasi Spirulina memberikan pengaruh berbeda $(p<0,05)$ terhadap aroma jelly drink spirulina. Hasil uji lanjut Dunn menunjukkan bahwa penambahan Spirulina pada konsentrasi 0,4\% memberikan pengaruh berbeda nyata dengan penambahan Spirulina konsentrasi 0,6\%, tetapi tidak memberikan pengaruh berbeda nyata dengan penambahan Spirulina konsentrasi $0,2 \%$. Penurunan kesukaan panelis terhadap aroma jelly drink yang ditambah dengan spirulina $0,4 \%$ diduga karena adanya pengaruh interaksi dengan komponen lain misalnya protein dan lemak yang menghasilkan aroma kurang disukai.

Spirulina komersial yang digunakan diduga telah mengalami proses pengeringan dengan suhu tinggi seperti pengeringan dengan spray dried yang mengakibatkan terbentuknya aroma yang kurang disukai. Proses pengeringan menggunakan suhu tinggi dapat meningkatkan kadar nitrogen non protein. Hasil penelitian Conesa et al. (2005) menyatakan bahwa proses pengolahan pada suhu $120^{\circ} \mathrm{C}$ mengakibatkan peningkatan nitrogen non protein dan menurunkan total nitrogen serta nitrogen protein. Carratu et al. 2003 menyatakan bahwa nitrogen non protein tersusun atas peptida, urea, amoniak, asam amino bebas. Adanya fraksi nitrogen non protein ini diduga menimbulkan aroma yang kurang disukai pada jelly drink yang ditambah spirulina.

Peningkatan konsentrasi Spirulina mengakibatkan penurunan nilai kesukaan panelis terhadap warna jelly drink, hal ini diduga karena terlalu pekatnya warna minuman dan adanya perubahan warna akibat proses pemasakan. Hasil penelitian Koca et al. (2006) menunjukkan bahwa semakin tinggi suhu pemasakan $\left(<70^{\circ} \mathrm{C}\right)$ dan juga perubahan $\mathrm{pH}$ menjadi lebih asam akan mempercepat degradasi klorofil sehingga warna berubah menjadi kecokelatan.

Peningkatan konsentrasi spirulina menurunkan nilai rata-rata kesukaan rasa dan daya sedot jelly drink. Melone et al. (2003) menyatakan bahwa peningkatan viskositas

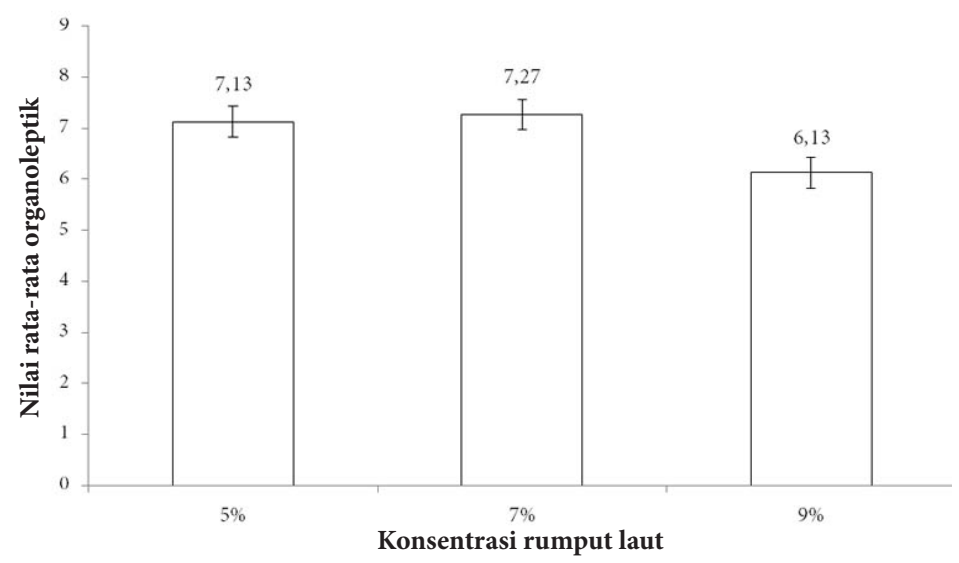

Gambar 1 Nilai rata-rata kesukaan daya sedot jelly drink 
akibat penambahan hidrokoloid dapat mempengaruhi persepsi seseorang terhadap aroma dan rasa. Semakin kental suatu bahan maka penerimaan terhadap intensitas rasa, bau dan cita rasa akan semakin berkurang dan semakin sulit untuk disedot.

\section{Hasil Uji Protein dan Aktivitas Antioksidan}

Protein dan aktivitas antioksidan menjadi kriteria yang digunakan dalam pemilihan formula terbaik. Spirulina tidak hanya memiliki kandungan protein yang tinggi, tetapi juga memiliki komponen aktif seperti antioksidan. Peningkatan konsentrasi Spirulina mengakibatkan peningkatan kadar protein jelly drink. Penambahan spirulina $0,2 \%$ berbeda nyata $(p<0,05)$ dengan penambahan spirulina $0,4 \%$ dan spirulina $0,6 \%$ (Tabel 1 ).

Aktivitas antioksidan jelly drink meningkat dengan semakin tingginya konsentrasi Spirulina yang ditambahkan (Tabel 1). Perbedaan konsentrasi Spirulina tidak memberikan pengaruh nyata $(p<0,05)$ terhadap aktivitas antioksidan. Aktivitas antioksidan jelly drink Spirulina dapat dikatakan sangat lemah karena nilai IC $_{50}$ lebih dari 200 ppm. Bahan digolongkan sebagai antioksidan sangat kuat apabila nilai $\mathrm{IC}_{50}$ kurang dari $50 \mathrm{ppm}$, kuat apabila nilai $\mathrm{IC}_{50}$ antara $50-100 \mathrm{ppm}$, sedang apabila nilai $\mathrm{IC}_{50}$ antara 100-150 ppm, lemah apabila nilai $\mathrm{IC}_{50}$ antara 150-200 ppm (Molyneux 2004).

\section{Formulasi Terbaik dengan Metode Bayes}

Hasil perangkingan dengan metode Bayes menunjukkan bahwa penambahan Spirulina
$0,4 \%$ menghasilkan total nilai pembobotan tertinggi $(2,08)$ dan menjadi formula terpilih. Penambahan Spirulina membantu dalam pemberian warna minuman dan pengkayaan gizi minuman. Formula terpilih kemudian dibandingkan dengan jelly drink penambahan Spirulina hasil kultivasi.

\section{Kultivasi dan Karakteristik Spirulina platensis}

Spirulina komersial memiliki kadar protein dan karbohidrat lebih tinggi dibandingkan Spirulina kultur namun memiliki kadar lemak yang lebih rendah (Tabel 2). Kultivasi yang dilakukan di laboratorium menggunakan media teknis dengan sumber nitrogen $\mathrm{CH}_{4} \mathrm{~N}_{2} \mathrm{O}$ (urea). Hasil penelitian Setyaningsih et al. (2011) menunjukkan bahwa penggunaan urea sebagai sumber nitrogen tidak memberikan pengaruh berbeda nyata terhadap kandungan pigmen dan juga komposisi kimia Spirulina. Danesi et al. (2002) menjelaskan bahwa urea dapat dihidrolisis secara spontan menjadi amoniak pada medium akali sehingga lebih mudah diasimilasi oleh Spirulina sebelum digunakan.

Kandungan protein yang lebih tinggi pada Spirulina komersial diduga karena konsentrasi $\mathrm{N}$ pada media yang lebih tinggi, sehingga aktivitas metabolisme tetap berlangsung dalam jangka waktu yang optimum. Produksi lemak yang lebih tinggi pada Spirulina kultur diduga karena perbedaan komposisi media dan perbedaan kondisi kultivasi. Hasil penelitian Colla et al. (2007), yakni suhu media kultivasi yang terlalu tinggi akan mengakibatkan

Tabel 1 Kadar protein dan aktivitas antioksidan jelly drink Spirulina komersial

\begin{tabular}{lcc}
\hline Konsentrasi Spirulina & Kadar protein & Aktivitas antioksidan $\left(\mathrm{IC}_{50}\right)$ \\
\hline 0,2 & $1,218^{\mathrm{a}}$ & $6070,0^{\mathrm{a}}$ \\
0,4 & $2,242^{\mathrm{b}}$ & $4818,5^{\mathrm{a}}$ \\
0,6 & $2,750^{\mathrm{b}}$ & $3363,5^{\mathrm{a}}$ \\
\hline
\end{tabular}

Keterangan: Huruf superskrip yang berbeda menunjukkan berbeda nyata pada taraf uji 5\% (dengan uji Duncan) yang dihitung berdasarkan basis kering 
Tabel 2 Hasil proksimat dan aktivitas antioksidan Spirulina platensis

\begin{tabular}{lcccc}
\hline \multirow{2}{*}{ Karakteristik } & \multicolumn{2}{c}{ Kandungan (\%) } & \multicolumn{2}{c}{ Spirulina kultur } \\
\cline { 2 - 5 } & \multicolumn{2}{c}{ Spirulina kultur } & 4,28 & \\
\cline { 2 - 5 } & Basis basah & Basis kering & Basis basah & Basis kering \\
\hline Kadar air & 93,15 & & 5,99 & 6,26 \\
Kadar abu & 0,95 & 13,87 & 61,06 & 63,79 \\
Kadar protein & 3,85 & 56,20 & 0,14 & 0,15 \\
Kadar lemak & 1,65 & 24,09 & 19,14 & 20,00 \\
Karbohidrat & & & 9,39 & 9,81 \\
- Serat kasar & 0,00 & 0,00 & & \\
- Serat pangan total & 0,77 & 11,24 & & \\
Antioksidan & & & & \\
- IC (ppm) & 16,25 & & & \\
\hline
\end{tabular}

penurunan produksi lemak. Qin (2005) juga menjelaskan bahwa intensitas lebih dari 60 $\mathrm{W} / \mathrm{m}^{2}$ dan konsentrasi $\mathrm{NaCl}$ lebih dari $0,15 \mathrm{M}$ dapat menurunkan produksi lemak.

Spirulina hasil kultur memiliki kandungan karbohidrat yang lebih rendah dibandingkan dengan karbohidrat Spirulina komersial, hal ini diduga karena adanya perbedaan konsentrasi nitrogen pada media kultivasi. Menurut Goksan et al. (2007) menyatakan bahwa pada media kultivasi yang kandungan nitrogennya tidak tercukupi akan mendukung produksi karbohidrat namun akan menurunkan produksi lemak dan protein.

Kadar abu spirulina kultur lebih tinggi dibandingkan spirulina komersial. Hasil penelitian Widianingsih et al. (2008) menunjukkan keberadaan unsur mineral dalam media kultur dapat mempengaruhi kadar abu. Spirulina hasil kultur dikultivasi menggunakan media teknis yang mengandung bahan pengisi, hal ini mengakibatkan media sukar larut sempurna terutama $\mathrm{NaHCO}_{3}$. Proses pencucian yang kurang bersih mengakibatkan adanya media yang ikut dan menambah kadar abu dalam bahan baku. Seytaningsih et al. (2011) menyatakan bahwa biomassa yang tidak dibilas dengan cukup air asam untuk membersihkan senyawa karbonat dapat mengandung kadar abu hingga 25\%.
Spirulina komersial maupun Spirulina hasil kultur mempunyai aktivitas antioksidan, tetapi sangat lemah (Tabel 1 dan 2). Sumber antioksidan yang terkandung dalam Spirulina diantaranya fikosianin, betakaroten, tokoferol, $\gamma$-linoleic acid dan komponen fenol (Merdekawati dan Susanto 2009). Tingginya $\mathrm{IC}_{50}$ spirulina komersial dan kultur diduga karena sampel yang digunakan tidak diekstrak terlebih dahulu. Hasil penelitian Herrero et al. (2005) menunjukkan bahwa spirulina yang diekstrak dengan etanol

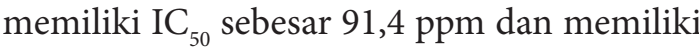
rendemen yang lebih besar dibandingkan pelarut heksan dan petroleum eter.

\section{Penelitian Utama Tahap 2 Hasil Uji Hedonik}

Uji kepentingan (Bayes) menghasilkan jelly drink Spirulina komersial 0,4\% sebagai produk terpilih. Penambahan Spirulina meningkatkan nilai kesukaan terhadap penampakan jelly drink namun tidak memberikan pengaruh berbeda $(p<0,05)$. Jelly drink Spirulina 0,4\% memiliki warna hijau sedangkan jelly drink kontrol memiliki warna kuning kecokelatan.

Penambahan spirulina mengakibatkan penurunan nilai kesukaan panelis terhadap aroma jelly drink spirulina (Gambar 2). Perbedaan jenis spirulina yang ditambahkan 


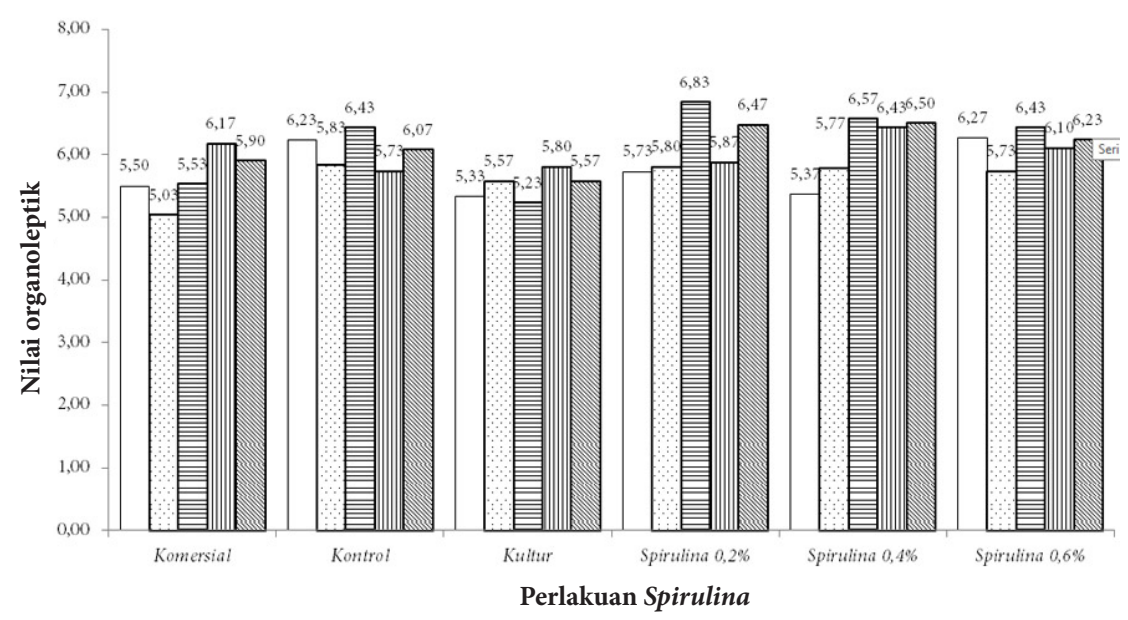

Keterangan: Aroma $(\square)$, warna $(\square)$, rasa $(\underline{0})$, penampakan $(\square)$, daya sedot $(\square)$

Gambar 2 Nilai rata-rata hedonik jelly drink spirulina komersial

tidak memberikan pengaruh berbeda $(p<0,05)$ terhadap aroma jelly drink. Aroma jelly drink spirulina yang kurang disukai diduga meningkatnya fraksi nitrogen non protein pada jelly drink spirulina. Carratu et al. 2003 menyatakan bahwa nitrogen non protein tersusun atas peptida, urea, amoniak, asam amino bebas. Penambahan esens leci $0,1 \%$ belum dapat menutupi aroma amis dari spirulina sehingga perlu peningkatan konsentrasi esens ataupun penggantian esens yang lebih sesuai.

Warna jelly drink yang ditambah dengan spirulina kultur yakni hijau, lebih disukai dibandingkan jelly drink yang ditambah dengan spirulina komersial yakni hijau kecokelatan namun tidak berbeda nyata $(p<0,05)$. Spirulina komersial berbentuk serbuk dan berwarna hijau agak cokelat yang diduga akibat pengeringan dengan suhu tinggi (Gambar 2). Hasil penelitian Koca et al. (2006) menunjukkan bahwa pengeringan pada suhu $70^{\circ} \mathrm{C}$ akan mengakibatkan degradari klorofil dan kecepatan reaksi degradasinya akan semakin meningkat dengan semakin meningkatnya suhu.

Jenis Spirulina memberikan pengaruh berbeda $(p<0,05)$ terhadap rasa jelly drink spirulina (Gambar 2). Uji lanjut Duncan menunjukkan bahwa kontrol berbeda nyata dengan penambahan spirulina kultur 0,4\%, tetapi penambahan Spirulina komersial 0,4\% tidak berbeda nyata dengan penambahan spirulina kultur 0,4\%. Jelly drink kontrol memiliki rasa yang lebih disukai karena komponen rasa yang berpengaruh hanya gula dan leci, sedangkan jelly drink Spirulina komponen rasa yang berpengaruh adalah gula, leci, dan rasa khas dari Spirulina.

Penambahan spirulina juga mengakibatkan penurunan nilai kesukaan terhadap daya sedot jelly drink. Spirulina mengandung makromolekul yaitu protein yang dapat berinteraksi dengan karagenan yang terkandung dalam rumput laut. Winarno (2008) menyatakan bahwa karagenan dapat berinteraksi dengan makromolekul yang bermuatan, misal protein, sehingga menghasilkan berbagai jenis pengaruh yaitu peningkatan viskositas, pembentukan gel, dan pengendapan. Interaksi ini mengakibatkan jelly drink lebih kental sehingga sulit disedot.

\section{Karakteristik Kimia Jelly Drink Spirulina}

Jenis Spirulina yang ditambahkan tidak memberikan pengaruh berbeda nyata $(p<0,05)$ terhadap kadar abu (Tabel 3). Kadar abu pada jelly drink berasal dari rumput laut dan spirulina. Kadar abu yang cukup tinggi pada jelly drink spirulina mengindikasikan bahwa minuman ini memiliki kandungan mineral yang cukup tinggi. Mineral yang 
Tabel 3 Hasil uji proksimat jelly drink Spirulina 0,4\%

\begin{tabular}{lccc}
\hline \multicolumn{1}{c}{ Parameter } & $\begin{array}{c}\text { Jelly drink } \\
\text { Spirulina komersial }\end{array}$ & $\begin{array}{c}\text { Jelly drink } \\
\text { Spirulina kultur }\end{array}$ & $\begin{array}{c}\text { Jelly drink } \\
\text { kontrol }\end{array}$ \\
\hline Kadar abu & $4,22^{\mathrm{a}}$ & $5,96^{\mathrm{a}}$ & $2,17^{\mathrm{a}}$ \\
Kadar protein & $2,20^{\mathrm{b}}$ & $0,78^{\mathrm{a}}$ & $0,39^{\mathrm{a}}$ \\
Kadar lemak & $0,15^{\mathrm{a}}$ & $0,45^{\mathrm{a}}$ & $0,12^{\mathrm{a}}$ \\
Serat pangan & $23,38^{\mathrm{b}}$ & $21,89^{\mathrm{b}}$ & $17,39^{\mathrm{a}}$ \\
Karbohidrat & $70,04^{\mathrm{a}}$ & $70,92^{\mathrm{a}}$ & $79,92^{\mathrm{b}}$ \\
Antioksidan (IC ${ }_{50}$ ) & $4818,50^{\mathrm{a}}$ & $4899,23^{\mathrm{a}}$ & $12428,50^{\mathrm{a}}$ \\
\hline Keterangan: Huruf superskrip yang berbeda menunjukkan berbeda nyata pada taraf uji \\
\multicolumn{4}{c}{ 5\% (dengan uji Duncan) yang dihitung berdasarkan basis kering }
\end{tabular}

terkandung dalam Eucheuma cottonii meliputi $\mathrm{Na}, \mathrm{K}, \mathrm{Ca}, \mathrm{Mg} \mathrm{Fe}, \mathrm{Zn}, \mathrm{Cu}$ dan iodium (Matanjun et al. 2009; Santoso et al. 2006) dan mineral yang terkandung dalam Spirulina platensis yakni $\mathrm{Na}, \mathrm{K}, \mathrm{Ca}, \mathrm{Mg}, \mathrm{Fe}, \mathrm{Cd}, \mathrm{Cr}$ dan $\mathrm{Cu}$ (Tokusoglu dan Onal 2003). Mineral dibutuhkan tubuh sebagai zat pembangun dan pengatur. Konsumsi jelly drink spirulina yang memiliki kandungan mineral tinggi ini dapat membantu mencukupi kebutuhan konsumsi mineral.

Kandungan lemak dalam jelly drink spirulina berkisar antara $(0,15-0,45) \%$ (bk). Lemak merupakan sumber energi yang lebih efektif dibandingkan karbohidrat dan protein. Lemak tersusun atas lemak tidak jenuh dan lemak jenuh. Spirulina mengandung berbagai asam lemak tidak jenuh yang baik untuk kesehatan. Hasil penelitian Tokusoglu dan Onal (2003) menunjukkan bahwa spirulina mengandung $\gamma$-linolenat acid (GLA) yang bermanfaat bagi penderita hiperkolesterolemia, alpha-linolenic acid (ALA), linolenicacid (LA), eicosapentaeonic (EPA), docosahexaenoic acid (DHA), dan arachidonic acid (AA). Konsumsi jelly drink spirulina yang mengandung EPA, DHA dan GLA diharapkan dapat memelihara dan meningkatkan kesehatan konsumen.

Protein memiliki peranan penting bagi tubuh. Protein merupakan sumber gizi utama dan memberikan sifat fungsional yang penting dalam membentuk karakteristik produk pangan misalnya pengental, pengemulsi, pembentuk gel, pembentuk buih dan lain-lain (Winarno 2008). Jelly drink spirulina kultur dan jelly drink kontrol memiliki kandungan protein lebih rendah dibandingkan jelly drink spirulina komersial. Jelly drink yang ditambahkan spirulina memiliki kandungan protein yang lebih tinggi dibandingkan dengan jelly drink yang beredar di pasaran. Minuman jelly drink yang beredar dipasaran tidak mencantumkan komposisi gizi yang terdapat dalam minuman tersebut. Minuman jelly drink yang beredar di pasaran memiliki kandungan protein yang lebih rendah dibandingkan jelly drink spirulina, diduga karena bahan-bahan yang digunakan tidak berpotensi mengandung protein.

Kandungan serat pangan pada jelly drink berkisar antara (21,89-23,38)\% (bk). Jenis spirulina memberikan pengaruh berbeda nyata $(\mathrm{p}<0,05)$ terhadap kadar total serat pangan (Tabel 3). Uji lanjut Duncan menunjukan bahwa jelly drink spirulina berbeda nyata dengan jelly drink kontrol, hal ini menunjukkan bahwa spirulina memiliki kandungan serat pangan. Beristain et al. (2006) menyatakan bahawa serat dapat mencegah timbulnya penyakit divertikular, kanker kolon, wasir, obesitas, diabetes melitus dan konstipasi, memperlambat pergerakan sisa makanan dalam saluran pencernaan tetapi tidak mengakibatkan penumpukan sisa makanan. 


\section{Aktivitas Antioksidan}

Jenis spirulina yang ditambahkan tidak memberikan pengaruh berbeda $(p<0,05)$ terhadap aktivitas antioksidannya (Tabel 3), hal ini menunjukkan bahwa rumput laut yang digunakan juga memiliki aktivitas antioksidan. Hasil penelitian Hardoko (2008) menunjukkan bahwa Eucheuma spinosum memiliki komponen antioksidan berupa fitol dan skualena. Aktivitas antioksidan dari ekstrak Eucheuma spinosum dengan pelarut etil asetat dengan $\mathrm{IC}_{50}$ sebesar 4741,5 ppm. Produk jelly drink komersial tidak mencantumkan informasi mengenai aktivitas antioksidan dan apabila terdapat aktivitas antioksidan diduga berasal dari antioksidan sintetik misalnya BHT. Jelly drink spirulina memiliki aktivitas antioksidan yang rendah, tetapi berasal dari sumber yang alami sehingga lebih aman untuk dikonsumsi.

\section{Angka Kecukupan Gizi Jelly Drink Spirulina platensis}

Jelly drink spirulina kultur dan komersial dengan serving size $200 \mathrm{~g}$ dapat menyumbangkan energi $92 \mathrm{kkal}$ dan $79 \mathrm{kkal}$. Jelly drink spirulina kultur maupun komersial dapat dijadikan sebagai minuman pembuka ataupun penutup dan tidak termasuk dalam menu utama. Konsumsi satu cup jelly drink dengan serving size $200 \mathrm{~mL}$ setara dengan meminum 2 kapsul suplemen spirulina. Dosis anjuran konsumsi suplemen Spirulina yang diproduksi oleh PT. Trans Pangan Indospina adalah dua kapsul/hari sehingga dianjurkan untuk mengonsumsi jelly drink spirulina tidak lebih dari 2 cup/hari. Pembatasan konsumsi ini karena spirulina mengandung asam nukleat dan purin. Jittanoonta et al. (1999) menyatakan maximum tolerable daily intake (MTD) dari spirulina adalah 4,33 g/kg berat badan yang dihitung berdasarkan acceptable daily intake asam nukleat yakni 2,6 g/orang. Konsumsi suplemen Spirulina sebanyak 10 tablet/hari masih diperbolehkan karena di dalam 10 tablet ( $20 \mathrm{~g}$ Spirulina murni) tersebut hanya mengandung $1,2 \mathrm{~g}$ asam nukleat.

\section{KESIMPULAN}

Formula jelly drink berbasis rumput laut (Eucheuma cottonii) dan spirulina komersial terpilih berdasarkan uji kepentingan adalah jelly drink dengan penambahan spirulina komersial $0,4 \%$. Jenis Spirulina (kultur dan komersial) yang ditambahkan tidak memberikan pengaruh nyata terhadap tingkat kesukaan panelis dan juga aktivitas antioksidan, namun memberikan pengaruh nyata terhadap kadar protein. Jelly drink spirulina kultur 0,4\% menyumbangkan energi lebih besar yakni 92 kkal dibandingkan dengan jelly drink spirulina komersial 0,4\% yakni $79 \mathrm{kkal}$.

\section{DAFTAR PUSTAKA}

[BSN] Badan Standardisasi Nasional. 2006. Cara Uji Kimia-Bagian 1: Penentuan Proksimat pada Produk Perikanan: SNI 012354. 2006. Jakarta: Badan Standardisasi Nasional.

[BSN] Badan Standardisasi Nasional. 2011. Petunjuk Pengujian Organoleptik dan atau Sensori pada Produk Perikanan: SNI 2346-2022. Jakarta: Badan Standardisasi Nasional.

Beristain CI, Sosa CF, Lobato-Calleros C, Pedroza-Islas R, Rodriguez ME, VerdeCalvo JR. 2006. Applications of soluble dietary fibers in beverages. Revista Mexicana de Ingenieria Quimica 3:81-95.

Carratu B, Boniglia C, Scalise F, Ambruzzi AM. 2003. Nitrogenous components of human milk: non-protein nitrogen, true protein and fee amino acids. Food Chemistry 81:357.

Colla LM, Furlong EB, Costa JAV. 2007. Antioxidant properties of Spirulina (Arthospira) platensis cultivated under different temperatures and nitrogen regimes. Brazilian Archives of Biology and Technology 50(1):161-167.

Conesa DP, Periago MJ, Ros G, Lopez G. 2005. Non-nitrogen in infant cereals affected by industrial. Food Chemistry 90:513-521.

Danesi EDG, Rangel-Yagui C, Carvalho 
JCM, Sato S. 2002. An investigation of effect replacing nitrate by urea in the growth and production of chlorophyll by Spirulina platensis. Biomass and Bioenergy 23:261-269.

Estrada JEP, Bescos PB, Fresno AMV. 2001. Antioxidant activity of different fractions of Spirulina platensis protean extract. Il Farmaco 56:497-500.

Goksan T, Zekeriyaoglu A, Liknur AK. 2007. The growth of Spirulina platensis in different culture systems under greenhouse condition. Turkish Journal Biology 31:4752.

Hardoko. 2008. Pengaruh konsumsi gel dan larutan rumput laut (Eucheuma cottonii) terhadap hiperkolesterolemia darah tikus wistar. Jurnal Teknologi dan Industri Pangan 19(2):97-104.

Herrero M, Pedro JM, Senorans J, Cifuentes A, Ibanez E. 2005. Optimization of accelerated solvent extraction of antioxidant from Spirulina platensis microalga. Food Chemistry 93:417-423.

Jittanoonta P, Cuptapun Y, Hengsawadi D, Limpanussorn J, Klungsub P. 1999. Food safety on utilization of solar-dried Thai Spirulina. Kasetsart Journal (Natural Science) 33:277-283.

Koca N, Karadeniz F, Burdurlu HS. 2006. Effect of $\mathrm{pH}$ on chlorophyll degradation and colour loss in blanched green peas. Food Chemistry 100:609-615.

Marimin.2004.TeknikdanAplikasiPengambilan Keputusan Kriteria Majemuk. Jakarta: PT Gramedia Widiasarana Indonesia. Hlm 17-21.

Matanjun P, Mohamed S, Mustapha NM, Muhammad K. 2009. Nutrient content of tropical edible seaweeds, Eucheuma cottonii, Caulerpa lentillifera and Sargassum polystum. Journal of Applied Phycology 21:75-80.

Mattjik AA, Jaya IM. 2006. Rancangan Percobaan dengan Aplikasi SAS dan Minitab. Bogor: IPB Press. Hlm 61-86.
Melone ME, Appelqvist IAM, Norton IT. 2003. Oral behaviour of food hydrocolloids and emulsions. Part 2, taste, and aroma release. Food Hydrocolloids 17:775-784.

Merdekawati W, Susanto AB. 2009. Kandungan dan komposisi pigmen rumput laut serta potensinya untuk kesehatan. Squalen 4(2):41-47.

Molyneux P. 2004. The use of the stable free radical diphenylpicryl-hydrazyl (DPPH) for estimating antioxidant activity. Songklanakarin Journal Science Technology 26(2):211-219.

Qin JG. 2005. Bio-hydrocarbon from algae impacts of temperature, light dan salinity on algae growth. A Report for the Rural Industries Research and Development Corporation. Australia: RIRDC Publication No. 05/025. Hlm 7-11.

Santoso J, Gunji S, Yoshie-Stark Y, Suzuki T. 2006. Mineral content of Indonesian seaweeds and mineral solubility affect by basic cooking. Food Science Technology Research 12(1):59-66.

Setyaningsih I, Saputro AT, Uju. 2011. Komposisi kimia dan kandungan pigmen Spirulina fusiformis pada umur panen yang berbeda dalam media pupuk. Jurnal Pengolahan Hasil Perikanan Indonesia 14(1):63-69.

Sulaeman A, Anwar F, Rimbawan, Marliyati SA. 1993. Metode Analisis Komposisi Zat Gizi Makanan. Bogor: Jurusan Gizi Masyarakat. Fakultas Pertanian Institut Pertanian Bogor.

Tokusoglu O, Onal MK. 2003. Biomass nutrient profiles of three microalgae: Spirulina platensis, Chorella vulgaris, and Isochrisis galbana. Journal of Food Science 68(4): 1144-1148.

Widianingsih, Ridho A, Hartati R, Harmoko. 2008. Kandungan nutrisi Spirulina platensis yang dikultur pada media yang berbeda. Ilmu Kelautan 13(3):167-170.

Winarno. 2008. Kimia Pangan dan Gizi. Bogor: M Brio Press. 